\title{
Science, society, and flagship species: social and political history as keys to conservation outcomes in the Gulf of California
}

\author{
$\underline{\text { Andrés M. Cisneros-Montemayor }}^{1}$ and Amanda CJ Vincent $^{2}$
}

\begin{abstract}
Socio-political issues are important in environmental policy outcomes but are often overlooked in conservation planning. We analyze the effects of historical social, political, and ecological contexts on conservation policy outcomes as applied to the Upper Gulf of California and Colorado River Delta Biosphere Reserve. A rushed implementation, perhaps necessary for the protection of endangered totoaba (Totoaba macdonaldi) and vaquita (Phocoena sinus), occurred with little community consultation, resulting in enduring disgruntlement among stakeholders that undermined its effectiveness. Overfishing and habitat degradation continue both inside and outside the reserve, and totoaba and vaquita remain Critically Endangered, with the latter's population estimated at approximately 90 individuals. Marine reserves can be useful, but when top-down enforcement is unfeasible, effective environmental policy requires full recognition and integration of political history and social structures and needs, and open discussion on trade-offs when win-win situations are not possible.
\end{abstract}

Key Words: Biosphere Reserve; flagship species; Gulf of California; social-ecological dynamics; totoaba; vaquita

\section{INTRODUCTION}

Stakeholder engagement and comanagement are crucial for successful environmental policy, often influencing outcomes more than the management schemes themselves (Gutiérrez et al. 2011). In the case of nature reserves, strategies for success have emerged (Lubchenco et al. 2003, Lundquist and Granek 2005, Mawdsley et al. 2009), but social and political aspects of implementation are underrepresented in scientific studies, despite these factors being critical for effectiveness (Alder et al. 1994, Kaiser 2005). This social context is vital (in democracies) given the arrays of objectives in mind and the varying time-horizons for assessing performance (Carr 2000).

Sustainable extraction remains integral to resource management, but conservation efforts, invoking both practical and moral arguments, increasingly form part of policy discussion. This has evolved beyond ecological protection into an awareness of the needs and benefits of ecologically sustainable industries (Ishwaran et al. 2008). However, conservation goals can lead to regulations which, though potentially useful, may alienate existing stakeholders (Prell et al. 2009). This can be unavoidable if, for example, fishing is prohibited in a coastal marine area, but can also stem from poor prior planning when designing and anticipating effects of environmental policies (Lundquist and Granek 2005).

The dearth of constructive interaction among parties who perceive mutually exclusive goals is currently evident in debates on the use of marine resources that are often overexploited but continue to sustain significant global industries (FAO 2012). Human pressures have also affected terrestrial ecosystems, but can be more difficult to address in marine settings, where organisms and habitat can be highly mobile and hard to see (Jones 2002). This difficulty may contribute to increasing proposals of marine protected areas (MPAs) as a catch-all strategy (Locke and Dearden 2005).
The upper (i.e., northernmost) Gulf of California (UGC) and Colorado River Delta (CRD) Biosphere Reserve (henceforth, "the Reserve"), in northern Mexico, is presented here as a model of a challenging conservation setting where continued stakeholder debate on human needs and ecological thresholds shapes policy. Like many developing countries, a large number of fishers, versatile boats and gear, and de facto open-access conditions have resulted in overfishing and ecosystem degradation (Sala et al. 2004, Cisneros-Montemayor et al. 2013). Actions are needed to protect wild species and spaces as well as the fisheries (Bobadilla et al. 2011), but there are key questions about which strategies to use. The flagship species for marine conservation in the Reserve are the totoaba (Totoaba macdonaldi), a critically endangered sciaenid fish, and the vaquita (Phocoena sinus), the world's most endangered marine mammal (D'agrosa et al. 2000, IUCN 2013). The Reserve area includes traditional fishing grounds, both for Indigenous groups and more recent commercial fisheries.

We analyze the process that led to the establishment and boundaries of the Reserve and review its outcomes to gain broadly applicable insights. Particular emphasis is placed on the environmental concerns driving action and the socio-political environment in which these actions took place. An important first step is to identify the motivation of stakeholders in the debate and the key players that affect processes and outcomes given the types of social networks in place (Prell et al. 2009, Reed et al. 2009). Analyzing the history of local resource management and the context in which policy emerged is crucial for understanding both positive and negative outcomes and improving future policies.

\section{STUDY AREA}

The UGC and CRD are highly productive, shallow marine and brackish water environments, with estuaries and mud flats providing major spawning areas for fishes and invertebrates

\footnotetext{
${ }^{1}$ Nereus Program and Ocean Canada, Institute for the Oceans and Fisheries, University of British Columbia, ${ }^{2}$ Project Seahorse, Institute for the Oceans and Fisheries, University of British Columbia
} 
(Galindo-Bect et al. 2000). It is also home to endemic and Critically Endangered marine species: the totoaba and the vaquita (IUCN 2013)

Since the early 1900s, the main human settlements are El Golfo de Santa Clara (popuation 2700) and Puerto Peñasco (population 31,000 ) on the Sonoran coast, and San Felipe (population 13,000) in Baja California (DOF 2009; Fig. 1). The Cucapá, Pima, and O'odham peoples that have historically inhabited the region were traditionally nomadic tribes, but partially settled along the northern CRD, notably near El Golfo de Santa Clara. These groups together total hundreds of people and, as with most Indigenous people throughout Mexico, are in precarious socioeconomic and cultural conditions after the degradation of lands and traditions under colonial and Mexican government (Navarrete-Linares 2008).

Fig. 1. Upper Gulf of California and Colorado River Delta Biosphere Reserve, including the core zone (CZ), buffer zone (BZ), and vaquita refuge area (VRA).

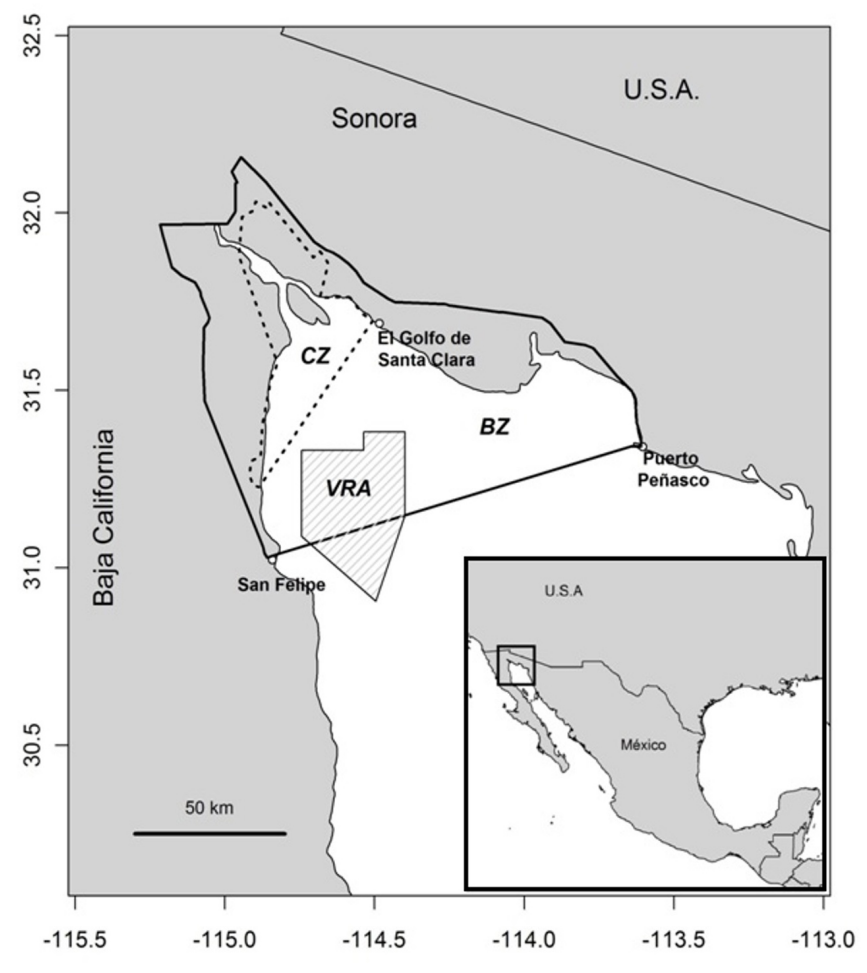

Fishing and some aquaculture drive the regional economy. The Mexican National Fisheries Chart (the official registry of Mexican fisheries) includes $\sim 25$ target species groups (> 300 species), with shrimps (Penaeidae) and sardines (Clupeidae) comprising approximately $50 \%$ of total landings and landed value (DOF 2010, CONAPESCA 2013). In the upper Gulf, key target species are shrimp (e.g., Litopenaeus stylirostris) and curvina (Cynoscion spp.); other bony fishes, sharks, and rays (e.g., Scomberomorus spp., Micropogonias spp., Mustelus spp., Squatina spp.) are seasonally important (Turk-Boyer and Cudney-Bueno 1998, Espinosa-Romero et al. 2014). Recently, jellyfish (Stomolophus meleagris) have become a highly valuable seasonal target species (López-Martínez and Álvarez-Tello 2013, CisnerosMata et al. 2014, Girón-Nava et al. 2015).

More than 20,000 registered (and many unregistered) artisanal fishing boats ( $\sim \mathrm{m}$ length open-deck fiberglass) and $\sim 1500$ larger industrial trawl and seine vessels operate along the Gulf (CONAPESCA 2007). Most fishers are organized into cooperatives of various sizes or work for larger industrial fishing firms (OECD 2006). Aquaculture, particularly for shrimp, has grown steadily and currently contributes approximately $60 \%$ of national shrimp production (CONAPESCA 2013), though it provides less employment compared to capture fisheries. There are concerns about environmental and social effects of aquaculture operations, specifically regarding pollution, habitat transformation, and a lack of integration of local communities in large-scale enterprises (Avilés-Quevedo and Vázquez-Hurtado 2006). Tourism is a very significant industry in the Gulf of California, though not yet well-established in the upper Gulf.

\section{The Biosphere Reserve}

The Reserve spans the Colorado River Delta and Estuary, and the northern (upper) Gulf of California, including the coastline, and is the largest aquatic reserve in Mexico $\left(9347 \mathrm{~km}^{2}\right)$. The Reserve is divided into core, buffer, and Vaquita Refuge areas (Fig. 1), and 22 subareas with their own restrictions (Table 1). It is shared by two states (Baja California and Sonora) and three municipalities; water use along the Colorado River involves seven U.S. states (notably, California, Colorado, and Arizona). Multiple Mexican agencies have some jurisdiction over the Reserve, including the National Protected Natural Areas Commission (CONANP), National Ecology Institute (INE), National Fisheries Institute (INP), National Aquaculture and Fisheries Commission (CONAPESCA), Ministry of the Environment and Natural Resources (SEMARNAT), Federal Environment Protection Office (PROFEPA), National Commission for Use and Knowledge of Biodiversity (CONABIO), and the Mexican Navy (SEMAR).

\section{HISTORY OF THE BIOSPHERE RESERVE}

Following from Rojas-Bracho et al. (2006), we divide our analysis into four periods defined by significant events related to science, society, and flagship species linked to the Reserve (Table 2). Transitions between these periods are marked by: (1) the end of freshwater flow from the Colorado River and the first description of the vaquita, (2) the first formal assessment of the vaquita, and (3) the decree of the Reserve.

\section{Preindustrial fisheries and first scientific studies (1900-1960)}

The UGC was an isolated region well into the 20th century, but nonetheless has a rich history of resource use. During the late 1800 s and early 1900s, it was a corridor for supply ships headed up the Colorado River, facilitating development of the southwestern United States (Mueller and Marsh 2002) until sequential damming of the river beginning in the early 1900s. This virtually eliminated water flow to Mexico by the mid-1960s and was disastrous for riparian and marine habitats; the Colorado River estuary underwent major changes, including increased sedimentation and a switch from hypo- to hypersaline conditions (Álvarez-Borrego 2003, Flessa 2004). 
Table 1. Restricted or prohibited activities in the Upper Gulf of California and Colorado River Delta Biosphere Reserve and pertinent laws in the Gulf of California. Summarized from the biosphere reserve management program (CONANP 2007).

\begin{tabular}{ll}
\hline \hline Region & Restricted or prohibited activity \\
\hline Gulf of California & Harm to marine mammals \\
& Sea turtle extraction \\
& Totoaba extraction \\
& $>25.4-c m$ mesh gillnets \\
Buffer zone & Low-selectivity fishing \\
& Habitat modification \\
& Trawling \\
& Gillnetting (restricted) \\
& $>15$-cm mesh gill or set nets \\
& Changes in ground use \\
& Construction \\
& Camping (restricted) \\
& Mining \\
& Resource extraction \\
& Habitat modification \\
& Fishing of any kind \\
Core zone & Changes in ground use \\
& Agriculture \\
& Aquaculture \\
& Tourism (restricted) \\
& Camping \\
& Diving \\
& Outboard engine boats \\
& Cattle grazing \\
\hline Various subareas $(>600,000$ ha) allow different types of fishing \\
subject to specific guidelines. \\
\end{tabular}

Marine resources were already exploited to some degree, mostly for trade and subsistence by Indigenous groups and Mexican settlers. The first intensive fishery was based in Guaymas, Sonora, in the early 1900s and targeted totoaba for their swim bladders, although this species was historically caught for consumption by Indigenous fishers. Totoaba fishing using harpoons and oar or sail-powered canoes (Bahre et al. 2000) expanded, and the dried swim bladders (buches) were sold for use in soups in China and by the Asian community in California. The lack of roadways or freezing capacity meant that most remaining totoaba meat was discarded. In 1924, however, two Americans drove the first truck of iced fish through then-uncharted desert from San Felipe to the U.S. border. This established a new trade route into southern California and Arizona and prompted the expansion of totoaba and other fisheries (Bureau of Marine Fisheries 1949, Bahre et al. 2000).

Evolving fishery practices and environmental changes beginning in the late 1920s led to the threat of extinction for totoaba. Like many sciaenid fish, totoaba form large spawning aggregations at the water surface (Erisman et al. 2010). Despite limited fishing capacity at that time, focused effort on spawning grounds increased catches from 296 tonnes in 1932 to 2286 tonnes in 1942 (Cisneros-Mata et al. 1995a). New cotton and nylon nets and motorized boats in the 1940s and 1950s allowed fishers to haul entire spawning aggregations of totoaba (Bahre et al. 2000), followed by the start of industrialized shrimp trawl operations which caught juvenile totoaba (machorros) incidentally. Coupled with the (then-unrecognized) effect of diminishing freshwater flow on recruitment, this led to rapid declines in totoaba populations and catch (Cisneros-Mata et al. 1995a, Lercari and Chávez 2007; Fig. 2).

Fig. 2. Index of historical landings of totoaba and shrimp (metric tonnes), Colorado River outflow into Mexico $\left(\mathrm{hm}^{3}\right)$, and vaquita abundance (individuals). Adapted from data in Cisneros-Mata et al. (1995a), and updated with data from CIRVA (2014), CONAGUA (2015), and FAO (2015). Indices are relative to the highest value for each time series.

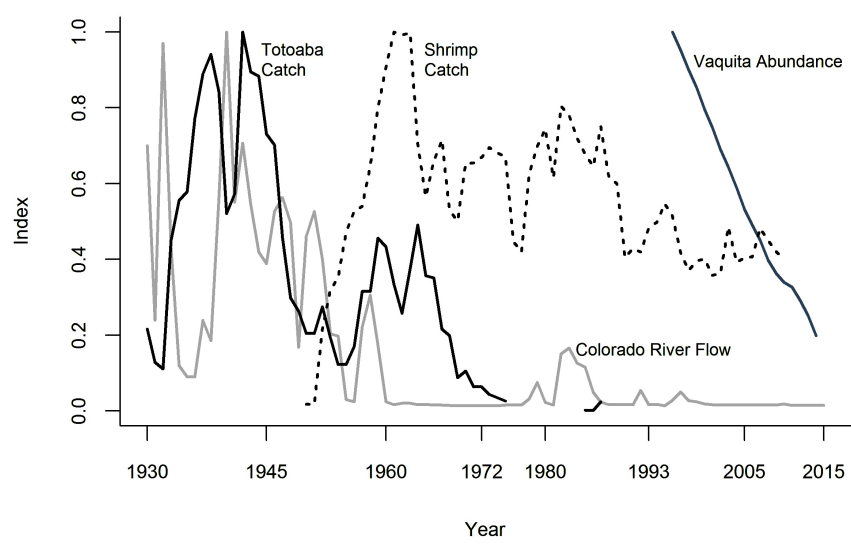

Despite continued industrialization, prevailing cooperative management kept fisheries rooted in local communities. Implemented in the 1930s, cooperative rights-based systems paralleled agricultural policy, granting resident communities exclusive and nontransferable rights over land use (or in this case, marine resources; OECD 2006). These policies emerged following the Mexican Revolution (1910-1920s) to address the inequalities of privatized and concentrated resource ownership that often involved virtual (or literal) slave labor.

In the 1950s, biologists from the United States and Mexico began studying totoaba fisheries amid plummeting catches (Berdegué 1955). Their research quickly identified the estuaries as crucial spawning and rearing areas for totoaba, and the first fisheries conservation policies were declared, including banning gillnets in the estuary area (DOF 1949). Enforcement was nonexistent, but a conceptual and legislative seed had been planted in recognizing the area's need for protection.

In 1958, the skull of an undescribed marine mammal was found by American biologists, who described it as Phocoena sinus and gave it the common name "cochito", attributed by local fishers (Norris and McFarland 1958). This unassuming new species, later renamed "vaquita", would eventually become the primary focus of debate, conflict, and an international conservation movement in the UGC.

\section{Industrial fisheries, science, and conservation advocacy (1960- 1990)}

As part of the modern environmental movement beginning in the 1960s, a number of scientists began work in the Gulf of California. Most research focused on fisheries and biology and ecology of 
Table 2. Timeline of social, political, economic, and ecological events before and after creation of the Upper Gulf of California and Colorado River Delta Biosphere Reserve.

\begin{tabular}{|c|c|c|}
\hline Historical context & Year & Event \\
\hline \multirow[t]{9}{*}{$\begin{array}{l}\text { Preindustrial fisheries and first } \\
\text { scientific studies (1900-1960) }\end{array}$} & 1909 & $\begin{array}{l}\text { Shipping through Colorado River ends with completion of Laguna Diversion Dam, } \\
\text { California/Arizona }\end{array}$ \\
\hline & 1910 & Commercial fishery for totoaba swim bladders begins \\
\hline & 1924 & First truck of totoaba meat driven to United States \\
\hline & 1936 & Completion of Hoover Dam \\
\hline & 1942 & Highest recorded totoaba catch \\
\hline & 1945 & First record of commercial shrimp catch in upper Gulf of California \\
\hline & 1949 & Mexico bans gillnets in Colorado River estuary \\
\hline & 1955 & First scientific publication on totoaba overfishing \\
\hline & 1958 & Description of Phocoena sinus ("cochito") \\
\hline \multirow{8}{*}{$\begin{array}{l}\text { Industrial fisheries, conservation } \\
\text { science, and advocacy (1960-1990) }\end{array}$} & 1961 & End of Colorado River flow into Mexico \\
\hline & 1970 & Mexican government accelerates fisheries development \\
\hline & 1972 & First marine Biosphere Reserve in Mexico, Laguna Ojo de Liebre \\
\hline & 1975 & Lowest recorded totoaba catch; permanent fishery closure \\
\hline & 1976 & $\begin{array}{l}\text { Totoaba listed as threatened by International Union for the Conservation of Nature } \\
\text { (IUCN) }\end{array}$ \\
\hline & 1982 & First publication on conservation status of vaquita \\
\hline & 1985 & First complete specimens of $P$. sinus reported \\
\hline & 1989-1990 & El Niño and economic reforms affect fishing industry \\
\hline Pre-enactment and decree of the & 1990 & United States embargoes imports of Mexican tuna \\
\hline \multirow[t]{7}{*}{ Reserve (1990-1993) } & 1990 & Vaquita listed as threatened by IUCN \\
\hline & 1990 & National Fisheries Bank declares bankruptcy \\
\hline & 1992 & Mexico hosts United Nations Conference on Responsible Fishing \\
\hline & 1992 & $\begin{array}{l}\text { Mexico creates national agencies for biodiversity (CONABIO), ecology (INE), and } \\
\text { environmental protection (PROFEPA) }\end{array}$ \\
\hline & 1993 & First systematic vaquita survey undertaken \\
\hline & 1993 & Proposal for the Reserve presented to government (March) \\
\hline & 1993 & The Reserve is adopted by presidential decree (June) \\
\hline \multirow[t]{8}{*}{$\begin{array}{l}\text { Evolution and current status (1994- } \\
\text { present) }\end{array}$} & 1994 & $\begin{array}{l}\text { North American Free Trade Agreement signed by Canada, United States, and Mexico } \\
\text { (January) }\end{array}$ \\
\hline & 1998 & Surveys confirm vaquita range extends outside Reserve \\
\hline & 2005 & Vaquita Refuge Area enacted to extend protection area \\
\hline & 2007 & Cucapá people officially allowed to fish in core area \\
\hline & 2008 & Vaquita survey suggests 57\% decline since 1997 \\
\hline & 2011 & Shrimp trawling allowed in buffer zone \\
\hline & 2012 & Bilateral agreement to restore Colorado River Delta \\
\hline & 2014 & Vaquita population estimated at 97 individuals \\
\hline
\end{tabular}

local species and was undertaken by the then-Ministry of Fisheries (SEPESCA) and academic institutions, including universities in Baja California, Sonora, California, and Arizona.

This period saw a rapid expansion in the fishing industry, built on subsidies and parastatal organizations as part of a national plan to shift labor away from agriculture and stimulate fish production (Hernandez and Kempton 2003, Valdéz-Gardea 2010). From 1970-1980, the national fleet doubled, and landings increased from 200 thousand to $>1$ million tons (CONAPESCA 2007). Investments included industrial (particularly small pelagic) fisheries and processing capacity and thousands of new artisanal vessels along the coasts.

The totoaba population remained severely depleted through targeted fisheries, bycatch, and impaired recruitment because of lack of freshwater flow (Lercari and Chávez 2007). These combined factors resulted in a historically low catch in 1975 and a subsequent ban on all totoaba fishing (DOF 1975). Protests against this ban were subdued, likely because of waning catches during the previous decade and the concurrent growth of other fisheries. In 1976, totoaba became the first marine fish to be designated as Endangered by CITES.

Little attention had been paid to vaquita since its description in 1958 , though it was thought to inhabit the uppermost portion of the Gulf and was recognized as a small population. In 1986, however, the first recorded specimens were caught in a gillnet set for totoaba research. This was also the first time that fishers' common name for the porpoise, vaquita (a rare sight even to them), was properly adopted (Brownell et al. 1987). Renewed interest in vaquita was followed by bycatch monitoring programs to estimate its population size, with a first estimate of $\sim 600$ individuals. Vaquita was designated as Critically Endangered in 1990, but little else was known about it (Rojas-Bracho et al. 2006). Research on vaquita biology, ecology, and distribution was led by an emerging conservation movement in Mexico, including scientists in various academic, nongovernmental, and governmental institutions.

In 1990, a U.S. embargo on Mexican tuna imports, imposed because of dolphin bycatch, significantly affected binational 
relations and future conservation actions. It dealt a severe blow to communities in northwest Mexico (mainly on the western coast of Baja California) and showed the potential repercussions of environmental guidelines (McDorman 1992). Originally suspended because of approved Mexican compliance with the Marine Mammal Protection Act, the embargo proceeded after the Earth Island Institute, a U.S.-based conservation nongovernmental organization (NGO), successfully sued the U.S. government. The decision stated that the time given to foreign fleets to prove compliance and the measure of bycatch employed were incompatible with statutes to ensure swift enforcement. The ruling acknowledged that these statutes were partly designed to protect U.S. tuna fisheries from competition with less-regulated fleets (U. S. District Court, Earth Island v Mosbacher, 1990). Resentment toward foreign conservation interests and their perceived link to foreign industry permeated Mexican society, including scientists, and is still palpable.

Adding to turmoil in the fishing sector, a strong El Niño in the late 1980s and early 1990s severely affected sardine and shrimp stocks, the backbone of fisheries along the entire Gulf (CisnerosMata et al. 1995b, Hernandez and Kempton 2003). This ecological blow would be followed by economic and political ones.

\section{Pre-enactment events and the decree of the Reserve (1990-1993)}

A series of rapid events culminated with the establishment of the Reserve in 1993 (DOF 1993). In 1988, the incoming administration was negotiating the North American Free Trade Agreement (NAFTA) with the United States and Canada, and a key issue was Mexico's perceived competitive industrial advantage due to weaker environmental policies (McDorman 1992, McGuire and Valdez-Gardea 1997), including bycatch of marine mammals. Mexico became proactive on environmental themes, including a strong showing at the Rio Earth Summit and the hosting of the Cancún Conference on Responsible Fishing in 1992 (Caddy and Griffiths 1995).

As the tuna embargo and NAFTA discussions fostered political will for visible conservation actions, the regional fishing industry was in crisis. The new federal government had been reshaping primary industries through privatization and withdrawal of below-market rate loans to cooperatives (Greenberg 2006). Furthermore, the federal bank funding fisheries initiatives, BANPESCA, was mired in mismanagement and corruption, and declared bankruptcy in 1990 (Hernandez and Kempton 2003). Amid continuing El Niño conditions, landings in the Gulf of California decreased by $>50 \%$ between 1989 and 1993, and the size of the fishing fleet showed the first and only (slight) decrease on record (CONAPESCA 2007). As cooperatives disbanded, many fishers were incorporated into new, more streamlined and profit-driven fishing firms or found other employment. In the upper Gulf, fishing income decreased by $80 \%$, and $50 \%$ of fishers in Puerto Peñasco became unemployed (Valdéz-Gardea 2010).

As the fishing sector struggled, fisheries scientists remained concerned about the totoaba population (Cisneros-Mata et al. $1995 a$ ) while conservation groups (mostly U.S.-based) dedicated efforts to vaquita protection (McGuire and Valdez-Gardea 1997). Despite high uncertainty regarding population status or bycatch rates, vaquita was perceived by conservation advocates and scientists as a victim of lax environmental policy in Mexican fisheries and management (Fleischer and Pérez-Cortés 1996), a negative for NAFTA discussions. In 1992, the Ministry of Urban Development and Ecology (its name reflecting an odd mandate) asked the Sonora government to develop a proposal to support the creation of a natural reserve, and the President created the International Committee for the Recovery of the Vaquita (CIRVA). In the following months, the North American Wetland Conservation Council, The Nature Conservancy, Conservation International, and the World Wildlife Fund funded workshops among scientists and conservation advocates to discuss the issue (SEMARNAP 1995).

A significant source of environmental degradation was the damming of the Colorado River by the United States that virtually stopped freshwater flow to the estuary since the early 1960s (Fig. 2). This resulted in declines of now-threatened native river fish populations, loss of important bird habitats, and fundamental shifts in oceanographic conditions (Mueller and Marsh 2002, Álvarez-Borrego 2003). Totoaba and shrimp reproduction appear to have suffered from reductions in freshwater flow, independent of fishing activity, that contributed to their decline and have hindered recovery (Galindo-Bect et al. 2000, Lercari and Chávez 2007; Fig. 2). Studies have shown that hypersaline conditions do allow totoaba survival, yet even point increases in freshwater flow result in increased productivity (Valdez-Muñoz et al. 2010). There is currently no evidence of habitat degradation effects on vaquita, though this has not been studied explicitly because of a focus on bycatch prevention (RojasBracho and Taylor 1999, Rojas-Bracho et al. 2006).

Early in 1993, one year before the NAFTA signing, the Presidency informed government agencies and NGOs of the intention to create a reserve, and an interagency proposal led by CIRVA was drafted (McGuire and Valdez-Gardea 1997). Although the vaquita distribution was unclear, unconfirmed reports and an ongoing survey suggested that it extended beyond the northernmost UGC (Fleischer and Pérez-Cortés 1996). The proposed lower bounds of the reserve were thus placed just north of the two largest towns in the region in a compromise between protection and social conflict (Fig. 1). A few months later, the first comprehensive vaquita survey revealed that these lines lay roughly along the middle of the population's likely core range (Gerrodette et al. 1995).

Public consultation, specifically including Indigenous groups, is highlighted in recent management plans (CDI 2009, DOF 2009), yet we could not find any information regarding such consultation processes during the planning stages of the reserve. The official account of the Reserve's history highlights a successful bid to "combine conservation efforts by government institutions, research and higher education centers, and non-government organizations ... to form the proposal that served as a basis for the establishment of the Biosphere Reserve" (CONANP 2007). There is no mention of public consultation, including with fishers, Indigenous communities, or other resource users, prior to the Reserve's establishment.

Despite a weakened fishing sector, there was strong resistance to the Reserve, particularly from the industrial shrimp fleet based in Guaymas, Sonora. To offset economic losses and quell dissent, new funding programs began within the National Solidarity Program to subsidize local fisheries and aquaculture and to promote tourism (OECD 2006). 
The first formal proposal for a biosphere reserve was presented to the government in March of 1993 (Brusca et al. 2001). Three months later, on June 10, the Reserve was decreed by thenPresident Salinas and passed into law. A Presidential decree is produced unilaterally by the executive on behalf of the nation and is technically irrevocable. In practice, it can be challenged by Congress or state governments with evidence that industry is significantly affected. Among those present at the enactment ceremony were President Salinas; his top aides; the Governors of Sonora, Baja California, and Arizona; and the U.S. Secretary of the Interior (McGuire and Valdez-Gardea 1997). The lofty stated goals of the Reserve are to:

\begin{abstract}
$[P]$ reserve the natural environments of the region and the more fragile ecosystems; ensure the balance and continuity of their ecological evolutionary processes; rationally benefit from its natural resources; to preserve the genetic diversity of wild and aquatic species of peninsular, insular and marine flora and fauna, particularly those that are endemic, threatened and in danger of extinction; enable regional socioeconomic development; promote applied research and technology, environmental and historical-cultural education and recreational and tourism activities; as well as maintain an adequate field for scientific research (DOF 1993).
\end{abstract}

\section{Evolution, current status, and future (1994-present)}

During the second half of the 1990s, a conservation lobby led by foreign-based NGOs with offices in Mexico pushed for wider marine conservation measures, including expanded Reserve boundaries. However, regional fisheries had recovered after economic restructuring and the return of key fish stocks following the 1989-1990 El Niño. Concurrently, fishers' real income within the Reserve decreased from 1994-2002 (Vázquez León et al. 2010). Conservation proposals were met with sometimes violent demonstrations, shaping a period of socio-political backlash (mainly from the fisheries and coastal development sector) against conservation groups perceived to have helped impose a reserve with few benefits for, and no consultation with, local communities (McGuire and Valdez-Gardea 1997).

By the late 1990s, arguments for vaquita conservation efforts were restrengthened as acoustic surveys confirmed that a significant part of its distribution lay outside the Reserve (Rojas-Bracho et al. 2006). A lengthy research and discussion process was characterized by strong emphasis on identifying and mitigating potential community economic losses (WWF et al. 2005, RojasBracho et al. 2006). A Reserve extension in which gillnetting is banned, the Vaquita Refuge Area (VRA) emerged in 2005, though still without full acceptance from local fishers. An indication of persistent disagreement is that the VRA was again enacted by presidential decree, by then-President Fox (DOF 2005), rather than as a product of broad consensus. Vaquita remains Critically Endangered (IUCN 2013), with an estimated population size of 245 individuals in 2008 (Gerrodette et al. 2011); in 2014, this was revised to 97 individuals (CIRVA 2014).

In the case of totoaba, recent studies and anecdotes suggest its population may be increasing, yet its life history and ongoing illegal catch probably preclude recovery to previous known abundances (Márquez-Farías and Rosales-Juárez 2013), and it remains Critically Endangered (IUCN 2013). Many fishing restrictions (Table 1) were never fully enforced or respected by fishers, but because totoaba fisheries are banned, current catch (which can be substantial; Cisneros-Montemayor et al. 2013) is illegal and therefore largely unknown. Unsustainable fishing continues both inside and outside the Reserve, resulting in declining overall catches of and profits from almost all species (Rojas-Bracho et al. 2006, Vázquez León et al. 2010), and combines with continued government aid to fishing fleets in a cycle of overexploitation and subsidization (OECD 2006, Espinoza-Tenorio et al. 2011).

Analyses of the Reserve reveal much more about costs than corresponding benefits. Aside from appeals for the vaquita's existence, local benefits from the Reserve have been limited to buy-back programs for gillnets or financial support for state governments to aid in enforcement (Rojas-Bracho et al. 2006, WWF and INE 2006). Fishers have increasingly questioned conservation measures and pressured government officials to ease restrictions (Méndez-Fierros 2005, Notimex 2008), even as all parties acknowledge the need for effective measures to ensure sustainability (Aragón-Noriega et al. 2010). For example, shrimp trawlers in Puerto Peñasco reached an agreement in 2011, brokered by the state government, to allow trawling within the buffer zone of the reserve (Ramírez 2011).

The importance of fishing for the Cucapá people was recognized in 2004 by the National Human Rights Commission, allowing them to fish in the core area of the Reserve under guidelines to protect endangered species (CNDH 2004, Luque Agraz and Gómez 2007). The issue of recognition of Indigenous peoples' rights is important to highlight in the context of the Reserve These communities are undoubtedly the most marginalized (both currently and historically) at both local and national levels, yet their challenges go beyond access to resources and include both endogenous and exogenous pressures that threaten their continued existence as peoples. This requires discussion and solutions that include but go far beyond ecology and fisheries.

In addition to fishing, tourism is a growing source of environmental and social pressures, primarily because of largescale development along the coast (Bryant 2007), including construction of hotels and marinas and appropriation of beaches and fresh water. This has catalyzed conflict between primarily local fishers and incoming workers and developers (ValdézGardea 2010). There have also been proposals to develop a recreational fishery for totoaba under the assumption that a catchand-release policy will mitigate potential negative effects. This must be assessed skeptically given that sciaenid fish have shown post-release mortality rates of up to $70 \%$, although mortality can be lower if the fish are handled properly (Lewin et al. 2006). Tourism may benefit parts of the region, provided that future development is subject to stringent ecological and social guidelines and regulations, but has been hindered by safety concerns and downturns in the global economy (Bryant 2007).

The sharpened conflict with fisheries interests during the early part of this period led to an evolution in conservation strategies, stressing stakeholder consultation and cooperation. After a period of trust building, more tempered dialogue resulted in positive advances. These include comanagement plans and selfimposed fishing restrictions to protect spawning aggregations for key species (Turk-Boyer and Cudney-Bueno 1998). These policies 
are localized within specific communities and fisher groups, but are becoming more important for regional management (Brusca et al. 2001). For example, fishers have requested spatial regulations to limit entry to larger industrial vessels, offered to participate in enforcement programs, and called for increased Colorado River flow that is linked to local productivity and species' distributions (Turk-Boyer and Cudney-Bueno 1998). In 2012, a bilateral agreement between the United States and Mexico backed a fiveyear pilot project to increase flow to the CRD to restore riparian habitat (Sonoran Institute 2013). It remains to be seen whether this will be fully executed, though increased recognition of the river's importance for this habitat is a positive development.

The capacity to implement management policies, however, does not necessarily mean these policies will be beneficial. Buy-back schemes (both permanent and temporary) were implemented in 2008 in the Reserve to reduce vessel numbers and use of gillnets for curvina. The outcomes were consistent with both theory and prior case studies: benefits accrued to limited groups within the fishing sector, with effective fishing effort likely unchanged or higher than before (Avila-Forcada et al. 2012). Such predictable outcomes of subsidies for the fishing sector help to explain why the long-term effects of bycatch reduction efforts are negligible (CIRVA 2014, Senko et al. 2014).

\section{DISCUSSION}

Impending loss of iconic species like the vaquita and totoaba can impel rapid action regardless of social support. Nevertheless, the social and political history and context of a place and people must be recognized and understood before enacting regulations. Foregoing a careful, yet not necessarily slow, process of collaborative policy design can result in legal designations that cannot be truly implemented and are unlikely to succeed (Reed et al. 2009). In the case of the Gulf of California, a determined conservation lobby and political opportunity led to the swift establishment of a large marine reserve; yet, it is currently a case where local people were alienated and the species' futures are not any more secure. Unsustainable practices continue because of tradition, culture, and economic needs of coastal (including Indigenous) communities, leading to the failure of the Reserve to meet its stated goals. Marine reserves can be useful, but recognizing an area's historical context is key for achieving social and ecological success (Espinoza-Tenorio et al. 2011).

As in most of the world, the ultimate cause of marine overexploitation is a combination of mostly open-access fisheries (Pauly et al. 2002) and a lack of investment in alternative livelihood opportunities (aside from marine tourism; Young 1999). The conservation objectives of large protected areas can benefit from parallel longer term plans for local social and economic improvements in education, gender equality, Indigenous rights, food security and sovereignty, and employment (Wilshusen et al. 2002). Ecological conservation contributes to achieving these goals, yet cannot be the sole mandate. An important aspect of such societal capacity building is that it should not be limited to fisheries, but rather exists within much broader (likely national level) social and economic policies with a long time horizon and explicit understanding of ecological capacity (Béné 2003, Carter 2003, Sumaila 2004). Without concerted policies that transcend fisheries-specific goals, sequential depletion of marine populations will continue, as occurred with totoaba and vaquita (Fig. 2); even recently emerged jellyfish fisheries are considered to be at maximum capacity in the Gulf (Cisneros-Mata et al. 2014).

Emphasis on flagship species as drivers for management action can undervalue other pressing issues, and research and may prove problematic for conservation efforts on the whole if these species indeed become extinct (Simberloff 1998, Agardy 2000, Wilshusen et al. 2002). Given the ongoing decline of vaquita (Fig. 2; CIRVA 2014), orienting the Reserve primarily around its preservation may backfire, and research should be broadened to include social drivers of fishing behavior, ecological dynamics, other natural and human stressors, and alternative conservation strategies (RojasBracho et al. 2006, Aragón-Noriega et al. 2010, Bobadilla et al. 2011). Captive breeding programs for totoaba, though most likely not for vaquita (Ames 1991), may contribute to conservation efforts (True 2012), but protection of wild populations is obviously key.

MPAs can be vital for conservation, though they have erroneously come to be expected to be a relatively straightforward solution to serve multiple objectives simultaneously (Alder et al. 2002, Locke and Dearden 2005). Based on a global synthesis of MPA performance (Lundquist and Granek 2005), there are characteristics of success that should occur throughout the entire process of problem identification, design, and implementation. These include stakeholder involvement, well-defined goals and objectives, a wide and transparent inclusion of scientific knowledge, comprehensive and ongoing monitoring of outcomes, and thoughtful design (Lundquist and Granek 2005). Despite the justified concerns regarding extinction of endemic species that bolstered its creation, the Reserve establishment process performed poorly under these criteria. Importantly, MPAs cannot offset wider management issues or ultimate causes of overexploitation (Carter 2003, Locke and Dearden 2005).

Extensive consultation can delay actions needed for critical conservation issues, but a well-designed process balances societal and scientific input such that they rapidly and continually inform each other (Ritchie and Ellis 2010). Ecological needs should emerge from scientific processes (Human and Davies 2010), but it is crucial to identify stakeholders and anticipate their interests before presenting policy suggestions (Vierros et al. 2006). Involving locals in data gathering and recognizing uncertainty in scientific studies (Slooten et al. 2000) can boost local trust in results and is invaluable for distinguishing scientific evaluations from advocacy positions. Outcomes from implemented policies should be measured systematically and shared openly and widely to inform adaptive changes (Walters 1986, Pullin and Knight 2003).

Following from these ideas, there are several strategies that could improve performance in the Reserve. First, creation of alternative livelihood opportunities and, more importantly, the personal and institutional capacity for individuals to create their own livelihood opportunities are crucial for local sustainable development (not exclusively dependent on marine resources). Second, fishers (both Indigenous and non-Indigenous) within the Reserve, who are the most burdened by restrictions, should benefit from resource access rights (Carter 2003, Grafton et al. 2006). This need not necessarily imply quota schemes (Costello et al. 2008, EspinosaRomero et al. 2014), which can have their own negative social 
effects (e.g., as has occurred in Canada; Pinkerton 2015), but certainly a formal recognition of local tenure rights (e.g., South Pacific Islands; Ruddle et al. 1992) to counteract prevailing marginalization and the perception that only biology and money dictate social-ecological dynamics (Béné 2003). Third, discussions must explicitly include social, economic, and ecological issues aside from direct effects to fisheries. This may present opportunities to redirect partial funding and subsidies toward potentially useful new research and policies, as has been done in cases throughout the world (see Cisneros-Montemayor et al. 2016). Fourth, the preceding points and other management discussions should advance collaboratively with local communities, entailing not only consultation but active participation (Berkes 2006, Kearney et al. 2007, Human and Davies 2010). This has led to positive results in similar cases that sometimes have even more difficult social and economic conditions (e.g., Europe, Southeast Asia, eastern Africa; Lundquist and Granek 2005).

Social, political, and economic factors most often underlie ecosystem degradation, but cannot be credibly addressed through ecological conservation policies alone. The Upper Gulf of California and Colorado River Delta Biosphere Reserve did not emerge solely from conservation interests, but for the interests to have been met, it needed to be implemented far more thoughtfully; as it is, its benefits remain unclear when measured against any intent. Even as we learn from this case to improve future policies, there may still be time to design and implement parallel shortand long-term strategies for conservation and social development. Refreshed collaborations between local communities, government, NGOs, and academic institutions are highly encouraging (Espinosa-Romero et al. 2014), but much work remains before the Reserve can be turned into a story of success.

\section{Responses to this article can be read online at:}

http://www.ecologyandsociety.org/issues/responses. $\mathrm{php} / 8255$

\section{Acknowledgments:}

This is a contribution from Project Seahorse and The Nippon Foundation Nereus Program. The authors thank Mr. Alejandro Robles (Noroeste Sustentable, A.C.), Dr. Miguel Cisneros Mata (Instituto Nacional de Pesca), Dr. Gloria Valdéz-Gardea (El Colegio de Sonora), Dr. Lorenzo Rojas-Bracho (Centro de Investigación Científica y de Educación Superior de Ensenada), and Lic. Victor Garcia (Government of Veracruz), who provided invaluable information and insights either through correspondence or in telephone interviews. We also thank Ngaio Hotte and three anonymous reviewers for their comments on the manuscript. Views expressed are solely the authors' and do not necessarily reflect those of persons interviewed. AMCM acknowledges support from CONACYT, the Mexican National Council for Science and Technology. ACJV thanks Guylian Chocolate Belgium and an anonymous donor for support through a partnership for marine conservation with Project Seahorse.

\section{LITERATURE CITED}

Agardy, T. 2000. Information needs for marine protected areas: scientific and societal. Bulletin of Marine Science 66(3):875-888. [online] URL: http://www.ingentaconnect.com/contentone/umrsmas/ bullmar/2000/00000066/00000003/art00025

Alder, J., N. A. Sloan, and H. Uktolseya. 1994. A comparison of management planning and implementation in three Indonesian marine protected areas. Ocean and Coastal Management 24 (3):179-198. http://dx.doi.org/10.1016/0964-5691(94)90037-x

Alder, J., D. Zeller, T. Pitcher, and U. R. Sumaila. 2002. A method for evaluating marine protected area management. Coastal Management 30(2):121-131. http://dx.doi.org/10.1080/089207502753504661

Álvarez-Borrego, S. 2003. Physical and biological linkages between the upper and lower Colorado Delta. Pages 1077-1089 in D. J. Rapport, W. L. Lasley, D. E. Rolston, N. O. Nielsen, C. O. Qualset, and A. B. Damania, editors. Managing for healthy ecosystems. Lewis Publishers, Boca Raton, Florida, USA. http:// dx.doi.org/10.1201/9781420032130.ch108

Ames, M. H. 1991. Saving some cetaceans may require breeding in captivity: work on bottlenose dolphin may be applied to the baiji. BioScience 41(11):746-749. http://dx.doi.org/10.2307/1311722

Aragón-Noriega, E. A., G. Rodríguez-Quiroz, M. A. CisnerosMata, and A. Ortega-Rubio. 2010. Managing a protected marine area for the conservation of critically endangered vaquita (Phocoena sinus Norris, 1958) in the upper Gulf of California. International Journal of Sustainable Development and World Ecology 17(5):410-416. http://dx.doi.org/10.1080/13504509.2010.500823

Avila-Forcada, S., A. L. Martínez-Cruz, and C. Muñoz-Piña. 2012. Conservation of vaquita marina in the northern Gulf of California. Marine Policy 36(3):613-622. http://dx.doi.org/10.1016/ j.marpol.2011.10.012

Avilés-Quevedo, S., and M. Vázquez-Hurtado. 2006. Fortalezas y debilidades de la acuicultura en México. Pages 69-86 in P. Guzmán Amaya and D. F. Fuentes Castellanos, editors. Pesca, acuacultura e investigación en México. Comisión de Pesca: CEDRSSA, Centro de Estudios para Desarrollo Rural Sustainable y la Soberanía Alimentaria, Mexico City, Mexico. [online] URL: http://www.cedrssa.gob.mx/?doc=457

Bahre, C. J., L. Bourillón, and J. Torre. 2000. The Seri and commercial totoaba fishing (1930-1965). Journal of the Southwest 42(3):559-575. [online] URL: http://www.jstor.org/stable/40170214

Béné, C. 2003. When fishery rhymes with poverty: a first step beyond the old paradigm on poverty in small-scale fisheries. World Development 31(6):949-975. http://dx.doi.org/10.1016/s0305-750x (03)00045-7

Berdegué, A. J. 1955. La pesquería de totoaba (Cynoscion macdonaldi) en San Felipe, Baja California. Revista de la Sociedad Mexicana de Historia Natural 16(1-4):45-78.

Berkes, F. 2006. From community-based resource management to complex systems: the scale issue and marine commons. Ecology and Society 11(1):45. [online] URL: http://www.ecologyandsociety. org/vol11/iss1/art45/ 
Bobadilla, M., S. Alvarez-Borrego, S. Avila-Foucat, F. LaraValencia, and I. Espejel. 2011. Evolution of environmental policy instruments implemented for the protection of totoaba and the vaquita porpoise in the upper Gulf of California. Environmental Science and Policy 14(8):998-1007. http://dx.doi.org/10.1016/j. envsci.2011.06.003

Brownell, R. L. Jr., L. T. Findley, O. Vidal, A. Robles, and N. S. Manzanilla. 1987. External morphology and pigmentation of the vaquita, Phocoena sinus (Cetacea: Mammalia). Marine Mammal Science 3(1):22-30. http://dx.doi.org/10.1111/j.1748-7692.1987. tb00149.x

Brusca, R. C., J. Campoy Fabela, C. Castillo Sánchez, R. CudneyBueno, L. T. Findley, J. Garcia-Hernández, E. Glenn, I. Granillo, M. E. Hendrickx, J. Murrieta, C. Nagel, M. Román, and P. TurkBoyer. 2001. A case study of two Mexican biosphere reserves: the upper Gulf of California/Colorado River Delta and Pinacate/Gran Desierto de Altar biosphere reserves. 2000 UNESCO Conference on Biodiversity and Society, Columbia University Earthscape. Columbia University, New York, New York, USA. [online] URL: http://www.sistemanodalsinaloa.gob.mx/archivoscomprobatorios/ 15_memoriaextenso/11481.pdf

Bryant, E. H. 2007. Barriers to sustainable coastal development in Puerto Peñasco, Sonora, Mexico. Thesis. Duke University, Durham, North Carolina, USA. [online] URL: http://hdl.handle. $\underline{\text { net } / 10161 / 277}$

Bureau of Marine Fisheries. 1949. The commercial catch of California for the year 1947 with an historical review 1916-1947. Fish Bulletin 74. California Department of Natural Resources, Division of Fish and Game, Bureau of Marine Fisheries, Sacramento, California, USA.

Caddy, J. F., and R. C. Griffiths. 1995. Living marine resources and their sustainable development: some environmental and institutional perspectives. FAO Fisheries Technical Paper 353. Food and Agriculture Organization, Rome, Italy. [online] URL: http://www.fao.org/docrep/003/v5321e/v5321e00.HTM

Carr, M. H. 2000. Marine protected areas: challenges and opportunities for understanding and conserving coastal marine ecosystems. Environmental Conservation 27(2):106-109. http://dx. doi.org/10.1017/s0376892900000151

Carter, D. W. 2003. Protected areas in marine resource management: another look at the economics and research issues. Ocean and Coastal Management 46(5):439-456. http://dx.doi. org/10.1016/s0964-5691(03)00017-6

CDI (Comisión Nacional para el Desarrollo de los Pueblos Indígenas). 2009. Consulta a los pueblos indígenas de la zona costera del Golfo de California referente al Ordenamiento Ecológico Marino. CDI, Mexico City, Mexico. [online] URL: http://www. cdi.gob.mx/dmdocuments/consulta_zona_costera_golfo_california. pdf

CIRVA (Comité Internacional para la Recuperación de la Vaquita). 2014. Report of the fifth meeting of the 'Comité Internacional para la Recuperación de la Vaquita' (CIRVA-5). CIRVA, Ensenada, Mexico. [online] URL: http://assets. worldwildlife.org/publications/713/files/original/2014 Vaquita Report Fifth Meeting of CIRVA.pdf?1408479198
Cisneros-Mata, M. A., A. A. Apolinar-Romo, M. A. CastellanosRico, L. M. Roldán-Luna, L. G. Rodríguez-Delgado, D. Rodríguez-Félix, J. Medina-Galván, and F. DomínguezDomínguez. 2014. Evaluación de la pesquería de medusa "bola de cañón" (Stomolophus meleagris) en la costa sonorense en 2014. Instituto Nacional de Pesca, CRIP Guaymas, Mexico.

Cisneros-Mata, M. A., G. Montemayor-López, and M. J. RománRodríguez. 1995a. Life history and conservation of Totoaba macdonaldi. Conservation Biology 9(4):806-814. http://dx.doi. org/10.1046/j.1523-1739.1995.09040806.X

Cisneros-Mata, M. A., M. O. Nevárez-Martínez, and M. G. Hamman. 1995b. The rise and fall of the Pacific sardine, Sardinops sagax Girard, in the Gulf of California, Mexico. Reports of California Cooperative Oceanic Fisheries Investigations 36:136-143.

Cisneros-Montemayor, A. M., M. A. Cisneros-Mata, S. Harper, and D. Pauly. 2013. Extent and implications of IUU catch in Mexico's marine fisheries. Marine Policy 39:283-288. http://dx. doi.org/10.1016/j.marpol.2012.12.003

Cisneros-Montemayor, A. M., E. Sanjurjo, G. R. Munro, V. Hernández-Trejo, and U. R. Sumaila. 2016. Strategies and rationale for fishery subsidy reform. Marine Policy, in press. http:// dx.doi.org/10.1016/j.marpol.2015.10.001

CNDH (Comisión Nacional de Derechos Humanos). 2004. Cuarta visitaduría general. Dirección General de Asuntos Indígenas, $\mathrm{CNDH}$, Mexico City, Mexico.

CONAGUA (Comisión Nacional del Agua). 2015. Volumen anual de agua del Río Colorado entregado por los Estados Unidos a México. CONAGUA, Secretaría de Medio Ambiente y Recursos Naturales, Mexico City, Mexico.

CONANP (Comisión Nacional de Áreas Naturales Protegidas). 2007. Programa de conservación y manejo Reserva de la Biosfera Alto Golfo de California y Delta del Río Colorado, México. Secretaría de Medio Ambiente y Recursos Naturales, CONANP, Mexico City, Mexico. [online] URL: http://www.conanp.gob.mx/ que hacemos/pdf/programas manejo/Final AltoGolfo.pdf

CONAPESCA (Comisión Nacional de Pesca). 2007. Anuario estadístico de acuacultura y pesca. Secretaría de Agricultura, Ganadería, Desarrollo Rural, Pesca y Alimentación, Mazatlán, Mexico. [online] URL: http://www.conapesca.sagarpa.gob.mx/ $\mathrm{wb} / \mathrm{cona} / \mathrm{cona}$ anuario estadistico de pesca

CONAPESCA (Comisión Nacional de Pesca). 2013. Anuario estadístico de acuacultura y pesca. Secretaría de Agricultura, Ganadería, Desarrollo Rural, Pesca y Alimentación, Mazatlán, Mexico. [online] URL: http://www.conapesca.sagarpa.gob.mx/ $\mathrm{wb} / \mathrm{cona} / \mathrm{cona}$ anuario estadistico de pesca

Costello, C., S. D. Gaines, and J. Lynham. 2008. Can catch shares prevent fisheries collapse? Science 321(5896):1678-1681. http:// dx.doi.org/10.1126/science.1159478

D'agrosa, C., C. E. Lennert-Cody, and O. Vidal. 2000. Vaquita bycatch in Mexico's artisanal gillnet fisheries: driving a small population to extinction. Conservation Biology 14(4):1110-1119. http://dx.doi.org/10.1046/j.1523-1739.2000.98191.x

DOF (Diario Oficial de la Federación). 1949. Acuerdo que modifica el sistema de captura de tiburón en la desembocadura del 
río Colorado y parte norte del Golfo de California o Mar de Cortés. Secretaría de Gobernación, Mexico City, Mexico.

DOF (Diario Oficial de la Federación). 1975. Acuerdo que establece veda para la especie totoaba (Cynoscion macdonaldi), en aguas del Golfo de California, desde la desembocadura del río Colorado hasta el río Fuerte, Sinaloa, en la costa oriental, y del río Colorado a Bahía Concepción, Baja California, en la costa occidental. Secretaría de Gobernación, Mexico City, Mexico.

DOF (Diario Oficial de la Federación). 1993. Decreto por el que se declara área natural protegida con el carácter de Reserva de la Biosfera, la región conocida como Alto Golfo de California y Delta del Río Colorado, ubicada en aguas del Golfo de California y los municipios de Mexicali, B.C., de Puerto Peñasco y San Luis Río Colorado, Son. Secretaría de Gobernación, Mexico City, Mexico.

DOF (Diario Oficial de la Federación). 2005. Acuerdo mediante el cual se establece el área de refugio para protección de la vaquita (Phocoena sinus). Secretaría de Gobernación, Mexico City, Mexico.

DOF (Diario Oficial de la Federación). 2009. Acuerdo mediante el cual se informa al público en general que la Comisión Nacional de Areas Naturales Protegidas ha concluido la elaboración del Programa de Manejo de la Reserva de la Biosfera Alto Golfo de California y Delta del Río Colorado, ubicada en aguas del Golfo de California y en los municipios de Mexicali, Estado de Baja California, y de Puerto Peñasco y de San Luis Río Colorado, Estado de Sonora. Secretaría de Gobernación, Mexico City, Mexico.

DOF (Diario Oficial de la Federación). 2010. Acuerdo por el que se da a concer la actualización de la Carta Nacional Pesquera. Secretaría de Gobernación, Mexico City, Mexico.

Erisman, B., I. Mascarenas, G. Paredes, Y. Sadovy de Mitcheson, O. Aburto-Oropeza, and P. Hastings. 2010. Seasonal, annual, and long-term trends in commercial fisheries for aggregating reef fishes in the Gulf of California, Mexico. Fisheries Research 106 (3):279-288. http://dx.doi.org/10.1016/i.fishres.2010.08.007

Espinosa-Romero, M. J., L. F. Rodriguez, A. H. Weaver, C. Villanueva-Aznar, and J. Torre. 2014. The changing role of NGOs in Mexican small-scale fisheries: from environmental conservation to multi-scale governance. Marine Policy 50 (A):290-299. http://dx.doi.org/10.1016/j.marpol.2014.07.005

Espinoza-Tenorio, A., I. Espejel, M. Wolff, and J. A. ZepedaDomínguez. 2011. Contextual factors influencing sustainable fisheries in Mexico. Marine Policy 35(3):343-350. http://dx.doi. org/10.1016/i.marpol.2010.10.014

FAO (Food and Agriculture Organization). 2012. The state of world fisheries and aquaculture. FAO Fisheries and Aquaculture Department, Rome, Italy. [online] URL: http://www.fao.org/ docrep/016/i2727e/i2727e00.htm

FAO (Food and Agriculture Organization). 2015. FishStatJ software for fishery statistical time series. FAO, Fisheries and Aquaculture Department, Rome, Italy. [online] URL: http:// www.fao.org/fishery/statistics/software/fishstatj/en

Fleischer, L., and H. Pérez-Cortés. 1996. Diagnosis del recurso vaquita, Phocoena sinus. Ciencia Pesquera (13):83-86. [online] URL: http://www.inapesca.gob.mx/portal/documentos/publicaciones/ cienciapesquera/CP13/cp13-12.pdf
Flessa, K. W. 2004. Ecosystem services and the value of water in the Colorado River delta and estuary, USA and Mexico: guidelines for mitigation and restoration. Pages 79-86 in International Seminar on Restoration of Damaged Lagoon Environments. Matsue, Japan. [online] URL: http://www.geo. arizona.edu/ceam/FlessaEcosystemServices.pdf

Galindo-Bect, M. S., E. P. Glenn, H. M. Page, K. Fitzsimmons, L. A. Galindo-Bect, J. M. Hernandez-Ayon, R. L. Petty, J. GarciaHernandez, and D. Moore. 2000. Penaeid shrimp landings in the upper Gulf of California in relation to Colorado River freshwater discharge. Fishery Bulletin 98(1):222-225. [online] URL: http:// fishbull.noaa.gov/981/17.pdf

Gerrodette, T., L. A. Fleischer, H. Pérez-Cortés, and B. VillaRamírez. 1995. Distribution of the vaquita, Phocoena sinus, based on sightings from systematic surveys. Pages 273-282 in A. Bjørge and G. P. Donovan, editors. Biology of the phocoenids: a collection of papers. Report of the International Whaling Commission Special Issue 16. International Whaling Commission, Cambridge, UK. [online] URL: https://archive.iwc.int/pages/terms.php? ref $=3487 \&$ search $=\% 21$ collection $34 \& \mathrm{k}=$ \&url $=$ pages $\%$

2Fdownload_progress.php

$\% 3$ Fref $\% 3$ D $3487 \% 26$ size $\% 3$ D $\% 26$ ext $\% 3$ Dpdf $\% 26 k^{\circ} \% 3$ D $\% 26$ search $\%$ 3D $\% 2521$ collection $34 \% 26$ offset $\% 3 \mathrm{D} 0 \% 26$ archive $\% 3$ D0 $\% 26$ sort $\% 3$ DDESC $\% 26$ order by $\% 3$ Drelevance

Gerrodette, T., B. L. Taylor, R. Swift, S. Rankin, A. M. JaramilloLegorreta, and L. Rojas-Bracho. 2011. A combined visual and acoustic estimate of 2008 abundance, and change in abundance since 1997, for the vaquita, Phocoena sinus. Marine Mammal Science 27(2):E79-E100. http://dx.doi.org/10.1111/j.1748-7692.2010.00438. $\underline{\mathrm{x}}$

Girón-Nava, A., C. López-Sagástegui, and O. Aburto-Oropeza. 2015. On the conditions of the 2012 cannonball jellyfish (Stomolophus meleagris) bloom in Golfo de Santa Clara: a fishery opportunity? Fisheries Management and Ecology 22(3):261-264. http://dx.doi.org/10.1111/fme.12115

Grafton, R. Q., R. Arnason, T. Bjørndal, D. Campbell, H. F. Campbell, C. W. Clark, R. Connor, D. P. Dupont, R. Hannesson, R. Hilborn, J. E. Kirkley, T. Kompas, D. E. Lane, G. R. Munro, S. Pascoe, D. Squires, S. I. Steinshamn, B. R. Turris, and Q. Weninger. 2006. Incentive-based approaches to sustainable fisheries. Canadian Journal of Fisheries and Aquatic Sciences 63 (3):699-710. http://dx.doi.org/10.1139/f05-247

Greenberg, J. B. 2006. The political ecology of fisheries in the Upper Gulf of California. Pages 121-148 in A. Biersack and J. B. Greenberg, editors. Reimagining political ecology. Duke University Press, Durham, North Carolina, USA.

Gutiérrez, N. L., R. Hilborn, and O. Defeo. 2011. Leadership, social capital and incentives promote successful fisheries. Nature 470(7334):386-389. http://dx.doi.org/10.1038/nature09689

Hernandez, A., and W. Kempton. 2003. Changes in fisheries management in Mexico: effects of increasing scientific input and public participation. Ocean and Coastal Management 46 (6-7):507-526. http://dx.doi.org/10.1016/s0964-5691(03)00032-2

Human, B. A., and A. Davies. 2010. Stakeholder consultation during the planning phase of scientific programs. Marine Policy 34(3):645-654. http://dx.doi.org/10.1016/j.marpol.2009.12.003 
Ishwaran, N., A. Persic, and N. H. Tri. 2008. Concept and practice: the case of UNESCO biosphere reserves. International Journal of Environment and Sustainable Development 7 (2):118-131. http://dx.doi.org/10.1504/ijesd.2008.018358

IUCN (International Union for the Conservation of Nature). 2013. IUCN Red List of endangered species. International Union for the Conservation of Nature, Gland, Switzerland. [online] URL: http://www.iucnredlist.org/

Jones, P. J. S. 2002. Marine protected area strategies: issues, divergences and the search for middle ground. Reviews in Fish Biology and Fisheries 11(3):197-216. http://dx.doi.org/10.1023/ $\underline{\text { A:1020327007975 }}$

Kaiser, M. J. 2005. Are marine protected areas a red herring or fisheries panacea? Canadian Journal of Fisheries and Aquatic Sciences 62(5):1194-1199. http://dx.doi.org/10.1139/f05-056

Kearney, J., F. Berkes, A. Charles, E. Pinkerton, and M. Wiber. 2007. The role of participatory governance and community-based management in integrated coastal and ocean management in Canada. Coastal Management 35(1):79-104. http://dx.doi. org/10.1080/10.1080/08920750600970511

Lercari, D., and E. A. Chávez. 2007. Possible causes related to historic stock depletion of the totoaba, Totoaba macdonaldi (Perciformes: Sciaenidae), endemic to the Gulf of California. Fisheries Research 86(2-3):136-142. http://dx.doi.org/10.1016/j. fishres.2007.05.010

Lewin, W.-C., R. Arlinghaus, and T. Mehner. 2006. Documented and potential biological impacts of recreational fishing: insights for management and conservation. Reviews in Fisheries Science 14(4):305-367. http://dx.doi.org/10.1080/10641260600886455

Locke, H., and P. Dearden. 2005. Rethinking protected area categories and the new paradigm. Environmental Conservation 32 (1):1-10. http://dx.doi.org/10.1017/s0376892905001852

López-Martínez, J., and J. Álvarez-Tello. 2013. The jellyfish fishery in Mexico. Agricultural Sciences 4(6):57-61. http://dx.doi. org/10.4236/as.2013.46a009

Lubchenco, J., S. R. Palumbi, S. D. Gaines, and S. Andelman. 2003. Plugging a hole in the ocean: the emerging science of marine reserves. Ecological Applications 13(S1):3-7. http://dx.doi. org/10.1890/1051-0761(2003)013[0003:pahito]2.0.co:2

Lundquist, C. J., and E. F. Granek. 2005. Strategies for successful marine conservation: integrating socioeconomic, political, and scientific factors. Conservation Biology 19(6):1771-1778. http:// dx.doi.org/10.1111/j.1523-1739.2005.00279.x

Luque Agraz, D., and E. Gómez. 2007. La construcción de la región del Golfo de California desde lo ambiental y lo indígena. Ra Ximhai 3(1):83-116. [online] URL: http://www.uaim.edu.mx/ webraximhai/Ej-07articulosPDF/Art $\% 204 \% 20$ Golfo.pdf

Márquez-Farías, J. F., and F. J. Rosales-Juárez. 2013. Intrinsic rebound potential of the endangered (Totoaba macdonaldi) population, endemic to the Gulf of California, México. Fisheries Research 147:150-153. http://dx.doi.org/10.1016/j.fishres.2013.05.009

Mawdsley, J. R., R. O’Malley, and D. S. Ojima. 2009. A review of climate-change adaptation strategies for wildlife management and biodiversity conservation. Conservation Biology 23 (5):1080-1089. http://dx.doi.org/10.1111/j.1523-1739.2009.01264. $\underline{x}$

McDorman, T. L. 1992. The 1991 U.S.-Mexico GATT panel report on tuna and dolphin: implications for trade and environmental conflicts. North Carolina Journal of International Law and Commercial Regulation 17:461-488.

McGuire, T. R., and G. C. Valdez-Gardea. 1997. Endangered species and precarious lives in the Upper Gulf of California. Culture and Agriculture 19(3):101-107. http://dx.doi.org/10.1525/ cag.1997.19.3.101

Méndez-Fierros, R. M. 2005. BC: protestan contra medidas ambientales. El Universal August 3, 2005. [online] URL: http:// archivo.eluniversal.com.mx/estados/58259.html

Mueller, G. A., and P. C. Marsh. 2002. Lost, a desert river and its native fishes: a historical perspective of the lower Colorado River. Information and Technology Report USGS/BRD/ITR-2002-0010. U.S. Geological Survey, Denver, Colorado, USA. [online] URL: http://www.fwspubs.org/doi/suppl/10.3996/092012-JFWM-084/ suppl_file/10.3996_092012-jfwm-084.s4.pdf

Navarrete Linares, F. 2008. Los pueblos indígenas de México: pueblos indigenas del México contemporáneo. Comisión Nacional para el Desarrollo de los Pueblos Indígenas, Programa de las Naciones Unidas para el Desarrollo, Mexico City, Mexico. [online] URL: http://www.cdi.gob.mx/dmdocuments/ monografia nacional pueblos indigenas mexico.pdf

Norris, K. S., and W. N. McFarland. 1958. A new harbor porpoise of the genus Phocoena from the Gulf of California. Journal of Mammalogy 39(1):22-39. http://dx.doi.org/10.2307/1376606

Notimex. 2008. Toman pescadores cucapás oficinas de SAGARPA en Mexicali. La Jornada May 21, 2008.

OECD (Organization for Economic Cooperation and Development). 2006. Agricultural and fisheries policies in Mexico: recent achievements, continuing the reform agenda. OECD, Paris, France. [online] URL: http://www.oecd.org/mexico/ agriculturalandfisheriespoliciesinmexico--recentachievementscontinuingthereformagenda.htm

Pauly, D., V. Christensen, S. Guénette, T. J. Pitcher, U. R. Sumaila, C. J. Walters, R. Watson, and D. Zeller. 2002. Towards sustainability in world fisheries. Nature 418(6898):689-695. http:// dx.doi.org/10.1038/nature 01017

Pinkerton, E. 2015. The role of moral economy in two British Columbia fisheries: confronting neoliberal policies. Marine Policy 61:410-419. http://dx.doi.org/10.1016/j.marpol.2015.04.009

Prell, C., K. Hubacek, and M. Reed. 2009. Stakeholder analysis and social network analysis in natural resource management. Society and Natural Resources 22(6):501-518. http://dx.doi. org/10.1080/08941920802199202

Pullin, A. S., and T. M. Knight. 2003. Support for decision making in conservation practice: an evidence-based approach. Journal for Nature Conservation 11(2):83-90. http://dx.doi.org/10.1078/1617-1381-00040

Ramírez, A. 2011. Después de 15 años de conflicto dan solución. El Caborquense January 19, 2011. 
Reed, M. S., A. Graves, N. Dandy, H. Posthumus, K. Hubacek, J. Morris, C. Prell, C. H. Quinn, and L. C. Stringer. 2009. Who's in and why? A typology of stakeholder analysis methods for natural resource management. Journal of Environmental Management 90(5):1933-1949. http://dx.doi.org/10.1016/j. jenvman.2009.01.001

Ritchie, H., and G. Ellis. 2010. 'A system that works for the sea'? Exploring stakeholder engagement in marine spatial planning. Journal of Environmental Planning and Management 53 (6):701-723. http://dx.doi.org/10.1080/09640568.2010.488100

Rojas-Bracho, L., R. R. Reeves, and A. Jaramillo-Legorreta. 2006. Conservation of the vaquita Phocoena sinus. Mammal Review 36(3):179-216. http://dx.doi.org/10.1111/j.1365-2907.2006.00088. $\underline{\mathrm{x}}$

Rojas-Bracho, L., and B. L. Taylor. 1999. Risk factors affecting the vaquita (Phocoena sinus). Marine Mammal Science 15 (4):974-989. http://dx.doi.org/10.1111/j.1748-7692.1999.tb00873. $\underline{\mathrm{X}}$

Ruddle, K., E. Hviding, and R. E. Johannes. 1992. Marine resources management in the context of customary tenure. Marine Resource Economics 7(4):249-273. http://dx.doi. org/10.1086/mre.7.4.42629038

Sala, E., O. Aburto-Oropeza, M. Reza, G. Paredes, and L. G. López-Lemus. 2004. Fishing down coastal food webs in the Gulf of California. Fisheries 29(3):19-25. http://dx.doi.org/10.1577/1548-8446 (2004)29[19:fdcfwi]2.0.c0:2

SEMARNAP (Secretaría del Medio Ambiente, Recursos Naturales y Pesca). 1995. Programa de manejo. Áreas naturales protegidas. Reserva de la Biósfera Alto Golfo de California y Delta del Río Colorado. SEMARNAP, Mexico City, Mexico.

Senko, J., E. R. White, S. S. Heppell, and L. R. Gerber. 2014. Comparing bycatch mitigation strategies for vulnerable marine megafauna. Animal Conservation 17(1):5-18. http://dx.doi. org/10.1111/acv.12051

Simberloff, D. 1998. Flagships, umbrellas and keystones: Is singlespecies management passé in the landscape era? Biological Conservation 83(3):247-257. http://dx.doi.org/10.1016/S0006-3207 (97)00081-5

Slooten, E., D. Fletcher, and B. L. Taylor. 2000. Accounting for uncertainty in risk assessment: case study of Hector's dolphin mortality due to gillnet entanglement. Conservation Biology 14 (5):1264-1270. http://dx.doi.org/10.1046/j.1523-1739.2000.00099-411. $\underline{\mathrm{X}}$

Sonoran Institute. 2013. Landmark binational agreement: minute 319. Sonoran Institute, Tucson, Arizona, USA. [online] URL: https://sonoraninstitute.org/files/pdf/minute-319-factsheet-09152013. pdf

Sumaila, U. R. 2004. Intergenerational cost-benefit analysis and marine ecosystem restoration. Fish and Fisheries 5(4):329-343. http://dx.doi.org/10.1111/j.1467-2679.2004.00166.x

True, C. D. 2012. Desarrollo de la biotecnia de cultivo de Totoaba macdonaldi. Dissertation. Universidad Autónoma de Baja California, La Paz, Mexico.
Turk-Boyer, P., and R. Cudney-Bueno. 1998. Pescando entre mareas del Alto Golfo de California. Una guía sobre la pesca artesanal, su gente y sus propuestas demanejo. Centro Intercultural de Estudios de Desiertos y Océanos, Puerto Peñasco, Mexico.

Valdéz-Gardea, G. C. 2010. Pesquerías globalizadas: revisitando a la comunidad marítima en el Alto Golfo de California. Estudios Sociales 18(35):135-163. [online] URL: http://www.scielo.org.mx/ scielo.php?script $=$ sci arttext\&pid $=$ S0188-45572010000100004

Valdez-Muñoz, C., E. A. Aragón-Noriega, A. Ortega-Rubio, C. A. Salinas-Zavala, J. A. Arreola-Lizárraga, S. HernándezVázquez, and L. F. B. Morales. 2010. Distribución y abundancia de juveniles de totoaba, Totoaba macdonaldi y la salinidad del hábitat de crianza. Interciencia 35(2):136-139.

Vázquez León, C. I., F. Almada, and J. Luis. 2010. Evaluación del impacto socioeconómico de la Reserva de la Biosfera Alto Golfo de California y Delta del Río Colorado en la actividad pesquera ribereña de San Felipe, Baja California, México. Región y Sociedad 22(47):31-51.

Vierros, M., F. Douvere, and S. Arico. 2006. Implementing the ecosystem approach in open ocean and deep sea environments: an analysis of stakeholders, their interests and existing approaches. UNU-IAS Report. United Nations University, Yokohama, Japan. [online] URL: http://collections.unu.edu/eserv/UNU:3096/ DeepSea_Stakeholders.pdf

Walters, C. J. 1986. Adaptive management of renewable resources. Macmillan, New York, New York, USA.

Wilshusen, P. R., S. R. Brechin, C. L. Fortwangler, and P. C. West. 2002. Reinventing a square wheel: critique of a resurgent "protection paradigm" in international biodiversity conservation. Society and Natural Resources 15(1):17-40. http://dx.doi. org/10.1080/089419202317174002

WWF and INE (Worldwide Fund for Nature and Instituto Nacional de Ecología). 2006. Conservación de la vaquita y su hábitat en el Alto Golfo de California: fondo de compensación económica para la pesca con redes de enmalle y el fomento de alernativas a la peca en el Alto Golfo de California. WWF and INE, Mexico City, Mexico. [online] URL: http://www.inecc.gob. mx/descargas/dgipea/pea-ar-2006-021.pdf

WWF, INP, and CONAPESCA (Worldwide Fund for Nature, Instituto Nacional de la Pesca, and Comisión Nacional de Pesca). 2005. Evaluación del impacto de un área de refugio para la vaquita marina sobre la pesca artesanal de San Felipe, B.C., El Golfo de Santa Clara y Puerto Peñasco, Son. WWF, INP, and CONAPESCA, Mexico City, Mexico.

Young, E. H. 1999. Balancing conservation with development in small-scale fisheries: Is ecotourism an empty promise? Human Ecology 27(4):581-620. http://dx.doi.org/10.1023/A:1018744011286 